${ }^{1}$ Faculty of Dentistry, Federal University of Juiz de Fora, Juiz de Fora, MG, Brazil.

${ }^{2}$ Department of Dental Clinic, Faculty of Dentistry, Federal University of Juiz de Fora, Juiz de Fora, MG, Brazil.
Corresponding author: Luan Viana Faria,

Fazenda da Reforma, sn, Araraí, Alegre, ES, 295350000, Brazil. Phone: +5528999523072; luanvfaria13@hotmail.com

Received: April 21, 2020

Accepted: October 12, 2020

\section{Medical Emergencies teaching in Dentistry undergraduate courses in Southeastern Brazil}

\author{
Luan Viana Faria ${ }^{1, *}(\mathrm{D})$, Yuri de Lima Medeiros ${ }^{1}$ (D), \\ Danielle Fernandes Lopes ${ }^{1}$ (D), Eduardo Machado \\ Vilela $^{2}$ (D), Neuza Maria Souza Picorelli Assis²
}

Aim: The aim of this study is to offer an overview of the Medical Emergencies (ME) discipline offer in Dentistry graduations in southeastern Brazil and to observe the curricular characteristics of the discipline when present. Methods: This cross-sectional documentary study analyzed the available curricular frameworks in the official websites of Higher Education Institutions (HEI) in southeastern Brazil registered on the Ministry of Education's e-MEC website. The data were analyzed and tabulated using the GraphPad Prism 8.1.2 software, being described by absolute and relative frequencies. Fisher's exact test was used to compare the proportions between public and private institutions. Results: Of the 176 courses in the Southeast, 144 were included in the study for providing access to the curriculum, 19 (13.19\%) were public and 125 (86.81\%) were private. Only $27(18.75 \%)$ of the HEI present the discipline of $\mathrm{ME}$, with a greater tendency of supply in private HEls (20.80\%) when compared to public HEls (5.26\%), but this difference was not statistically significant ( $p>0.05$ ). As a positive aspect, the discipline is predominantly mandatory (88.88\%), and the with regard to the teaching methodology is predominantly theoretical (68.18\%). The average workload is 50.14 hours (SD=19.54). Conclusions: In only $18.75 \%$ of the dental institutions in Southeast Brazil, ME discipline were offered. When offered, the discipline is predominantly theoretical and mandatory. This study raises an important discussion regarding the need to include specific and mandatory subjects on ME in the dentistry curricula in Brazil and reflects the need to update and standardize the national curricular guidelines for dentistry.

Keywords: Education, dental. Emergency service, hospital. First aid. Dentistry. 


\section{INTRODUCTION}

Dental surgeons must be prepared to manage possible medical emergencies (ME) that may arise in their daily professional practices ${ }^{1,2}$. In such situations, professionals and their teams need to be confident and up to date with their skills in order to provide initial treatment of quality ${ }^{3}$. Despite the consensus on the importance of training dental surgeon in this subject, several national ${ }^{4-7}$ and international studies ${ }^{8-14}$ show unsatisfactory results by demonstrating low knowledge and confidence of professionals in managing ME and first aid.

Based on these aspects, in recent years there has been a change in medical emergency management teaching methodologies for undergraduate students in many developed countries as an attempt to improve their management outcomes ${ }^{15-20}$. Moreover, in some countries, emergency medical training is formally part of undergraduate dental programs, and the example is the United States, which has been offering the discipline since $1981^{21}$.

In Brazil, the Federal Council of Dentistry (CFO) determined that all specialization courses should include in their programs the discipline of Medical Emergency in Dentistry, with a minimum workload of 15 hours ${ }^{22}$. Arsati et al. ${ }^{4}(2010)$ point out that it is unacceptable that this discipline is compulsory only for postgraduate programs, since any practitioner may face a medical emergency during clinical practice, regardless of their level of education and specialty. A national study has shown that Brazilian undergraduate dentistry students have only superficial knowledge about medical emergencies $^{23}$. With this, the formation of a generalist dentist is compromised, bringing insecure and unprepared professionals to the Brazilian job market.

Although several studies assess the knowledge of students and professionals in the management of ME, few studies discuss the factors that contribute to the persistence of these unsatisfactory results. The poor approach of this content during graduation may be one of the reasons why dental surgeon dentists still demonstrate a low ability to manage ME. In addition, this study is also useful because there are no reports in the literature regarding the comparative assessment between the provision of the ME discipline from public and private Brazilian institutions. Therefore, the objective of this paper is to draw an overview of the insertion of the ME discipline in the dentistry graduations of southeastern Brazil, and observe the curricular characteristics of the discipline when present.

\section{MATERIALS AND METHODS}

This is a cross-sectional and documentary evaluation study, in which the curricular matrices of the dentistry graduations were collected on the official institutional websites of the colleges, or via e-mail, through the coordinators of the dentistry courses. The search for discipline in the curricular matrices was carried out by two independent evaluators previously trained and calibrated. Information collected that differed between the two researchers was checked by a third evaluator.

The following variables were studied: location of institutions by states of the federation; HEl administrative category: public or private; insertion and offer of the 
discipline: presence or absence; nature of the curricular component: mandatory or non-mandatory; teaching methodology: theoretical or theoretical-practical content and total workload.

The sample of this research consists of all dentistry schools located in the southeast region of the country in active situation in March 2019, registered in the e-MEC portal of the Ministry of Education and Culture ${ }^{24}$ which is regulated by Normative Ordinance No. 21, of December 21, 2017. ${ }^{25}$ The collection period of the curricular grids was from March to June 2019.

Institutions were excluded from the sample according to the following criteria: did not have an official website and did not provide virtual media; did not present their complete curriculum available; did not open the dentistry course; and did not answer the e-mail after waiting for a deadline of two months, in case of absence of the curriculum on the institutional website. The collection period of the curricular grids was from March to June 2019. As it is a documentary evaluation study in the public domain, the approval of the Ethics Committee is waived.

Different poles of the same institution were considered in the composition of the final show, as well as institutions that offered the dentistry course in more than one modality, whether morning, afternoon, night or full, were treated as independent data, since the curricular matrix may vary between these situations, even within the same institution.

The statistical software used to analyze the variables was GraphPad Prism 8.1.2 (GraphPad Software Inc., La Jolla, CA, USA), which was analyzed using descriptive statistics, absolute (n) and relative (\%) frequency. The statistical test used for comparison was Fisher's Exact Test. The adopted significance level was 5\%.

\section{RESULTS}

We identified 176 dental schools, of which 32 were excluded for not meeting the study inclusion criteria; one did not have an official website and did not provide virtual means of communication; six did not open the course and 25 did not respond to the email after the two-month period. It was necessary to consult $33 \mathrm{HEls}$ via e-mail, obtaining a response rate of $24.24 \%$. The final research sample consisted of 144 institutions (81.82\%), 10 (6.94\%) located in the state of Espírito Santo (ES), 51 (35.41\%) in Minas Gerais (MG), 21 (14.58\%) in Rio de Janeiro (RJ) and 62 (43.05\%) in São Paulo (SP). According to the administrative category, Brazilian dental schools may be public or private. The sample of this study consisted of 125 (86.80\%) private and 19 (13.19\%) public schools.

Regarding the offer and insertion of the discipline, other names were found in the curriculum as "Basic life support" and "First Aid". In general, only 18.75\% of the colleges offered the discipline in their pedagogical plans. For the variable nature of the discipline, out of the 27 institutions that provided this information, it was observed that discipline is compulsory in $88.88 \%$ of the courses, compared to $11.12 \%$ of institutions in which the discipline is optional. The prevalence of the discipline taking into account the nature of the institutions is described in Table 1. 
Table 1. Prevalence and association test of the discipline of Medical Emergencies according to the administrative nature of dental schools in southeastern Brazil, 2019.

\begin{tabular}{|c|c|c|c|c|}
\hline \multirow{3}{*}{ Variables } & \multirow{2}{*}{\multicolumn{2}{|c|}{$\begin{array}{c}\mathrm{n}(\%) \\
\begin{array}{c}\text { Administrative nature of } \\
\text { dental schools }\end{array}\end{array}$}} & \multirow{3}{*}{$\begin{array}{c}\text { n (\%) } \\
\text { HIE public + } \\
\text { HIE private }\end{array}$} & \multirow{3}{*}{$\begin{array}{c}\text { p-value } \\
\text { (HIE public } x \\
\text { HIE private) }\end{array}$} \\
\hline & & & & \\
\hline & HIE public & HIE privete & & \\
\hline Insertion and Offer $(n=144)$ & & & & 0.1264 \\
\hline Present & $1(5.26 \%)$ & $26(20, .0 \%)$ & $27(18.75 \%)$ & \\
\hline Absent & $18(94.74 \%)$ & $99(79.20 \%)$ & $117(81.25 \%)$ & \\
\hline Nature of the discipline $(n=27)$ & & & & $>0.9999$ \\
\hline Compulsory & $1(100.00 \%)$ & $23(88.46 \%)$ & $24(88.89 \%)$ & \\
\hline Optional & $0(0.00 \%)$ & $3(11.54 \%)$ & $3(11.11 \%)$ & \\
\hline Teaching Methodology $(n=22)$ & & & & 0.3182 \\
\hline Exclusively theoretical contente & $0(0.00 \%)$ & $15(71.43 \%)$ & $15(68.18 \%)$ & \\
\hline Conjugated practical methodologies & $1(100.00 \%)$ & $6(28.57 \%)$ & $7(31.82 \%)$ & \\
\hline
\end{tabular}

Absolute (n) and relative (\%) frequency of ME subject to $\mathrm{HEl}$ administrative category. Fisher's exact test $(\mathrm{p}<0.05)$.

In private institutions, regarding teaching methodology, 22 institutions offered this information. In institutions which the discipline is only theoretical, four of them (26.66\%) offer it in the Distance Learning modality (DL) and in 11 (73.33\%), in the in-person modality. Only seven dental schools offer practical ME courses in their curriculum.

Regarding the workload, 21 courses offered this information in the curriculum matrices. The average workload was $50.14 \mathrm{~h}(\mathrm{SD}=19.54)$. The workload per state of the federation is shown in Figure 1.A. Analyzing this variable according to the administrative category of the institutions, private schools had an average workload of $51.90 \mathrm{~h}$ $(S D=18.27)$, while in public colleges the only school offering the subject had a workload of $15 \mathrm{~h}$. The minimum workload was $15 \mathrm{~h}$, and the maximum workload was $80 \mathrm{~h}$, with a median of $40 \mathrm{~h}$.

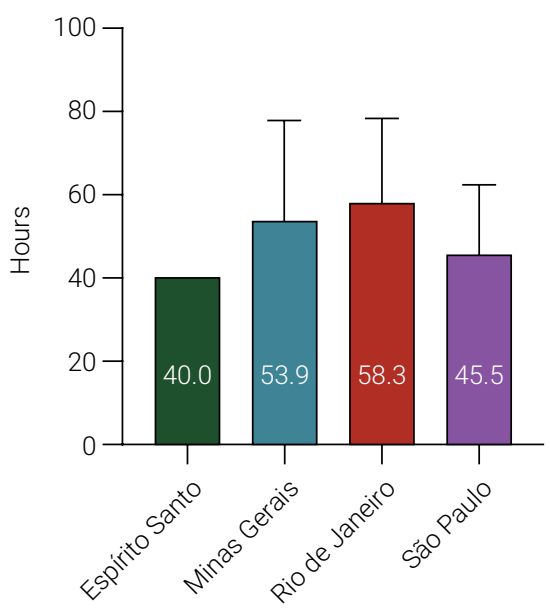

Figure 1. Average workload of the discipline of medical emergencies offered by dental schools by states of the federation ( $E S n=3 ; M G n=9 ; S P n=6 ; R J ~ n=3$ ) in southeastern Brazil, 2019. 


\section{DISCUSSION}

ME management is of crucial importance in dentistry practice and the starting point of training in this area is the undergraduate course in Dentistry ${ }^{26}$. Nevertheless, the results of this study show that Brazilian dental schools are outdated in the teaching of $\mathrm{ME}$, as most of the institutions surveyed (86.81\%) fail to offer a specific subject-oriented discipline in their curriculum. Aggravating this picture, less than a third of institutions reserve practical content subjects in their curriculum matrices, although studies show that participation in hands-on training easily raises students' awareness of the importance of $\mathrm{ME}$, as well as self-confidence in emergency management ${ }^{17,19}$. As a positive aspect, our study observed that in colleges that the discipline is offered, the tendency is to be mandatory, ensuring that all professionals trained in the institution had contact with the subject during graduation. According to our literature review, this is the first study to evaluate the supply of ME disciplines in a sample of dentistry courses in Brazil, as well as to compare how this discipline is distributed between public and private $\mathrm{HEl}$.

In Brazil, the opinion of National Education Council / Higher Education Chamber $n^{0} 803 / 2018^{27}$ that deals with the revision of the National Curriculum Guidelines of the undergraduate course in Dentistry in the country, defines "the emergency approach and the basic life support in case of accidents that compromise the life and the individual's health" among the essential curricular contents of the undergraduate course in Dentistry, within the Humanities and Social Sciences axis. In addition, Law 5,081 of August 24, $1966^{28}$, which regulates dental practice in Brazil, states that Brazilian dental surgeon can prescribe and apply emergency medication in the event of serious accidents that compromise the patient's life and health. Despite these guidelines and attributions, the discipline of ME is not described as compulsory to be included in the pedagogical projects of undergraduate courses, and it is up to the institution to choose whether or not to offer it in the curriculum matrices, as proposed by Law No. 9,39429, in its article 5329, which guarantees didactic autonomy to dentistry institutions.

Except in emergencies caused by trauma, dental surgeon can find almost all forms of ME in their offices, such as fluctuating consciousness, unconsciousness, chest pain-related problems, hypoglycemia, generalized seizure, and adverse drug reactions ${ }^{30}$. Therefore, dental professionals must be able to perform basic maneuvers in ME situations, both general practitioners and specialists, to ensure the health quality and integrity of patients, until they are able to receive specialized care. However, in emergency situations, it is common for a rescuer to go through a situation of panic or indecision, resulting in increased morbidity and mortality for the patient, given the potential delay in response time to intensive care ${ }^{31}$ reflecting the need for good care subject training to assure that professionals are calm and secure to deal with the situation.

An Australian study ${ }^{32}$ evaluated patients' perceptions of ME in Dentistry and their expectations for dental surgeon' management, noting high patient expectations regarding dentists' general medical knowledge. Nevertheless, many studies support the lack of preparation of students ${ }^{23,26,33-35}$ and professionals ${ }^{4-14}$ in managing ME, concluding that the subject should be addressed more deeply in dental education ${ }^{11,23}$, and for graduate dentists, refresher courses and workshops should be more frequently considered ${ }^{9}$. 
In this present study noted that few institutions offer practical content in ME disciplines, which does not seem to follow the trend in developed countries, where courses are moving away from just didactic-theoretical instruction, and incorporating regular practical simulation training into the provision of education ${ }^{15,16,18,19}$. These exercises help dental professionals and staff to feel more confident in their duties during emergency situations, improving their level of knowledge and overall readiness ${ }^{15-17,19}$. The use of simulators can be expensive as it may require the purchase of various mannequins and advanced life support simulators, but the skill acquisition level and positive student feedback seem to justify this expense ${ }^{18}$. Therefore, the existence of a specific theoretical-practical discipline in undergraduate studies is essential for the preparation of future professionals to lead with ME. The course introduces the student to a weekly experience on the subject, allowing him to perform regular emergency exercises to reinforce learning.

A US study published in $2018^{2}$ assessed the knowledge and preparation of professionals, skilled residents, and faculty members. It has observed that participants who had recently graduated or were still in school were able to treat ME cases more appropriately and often than the other participants. This finding positions the dental school as a valuable component in the preparation of clinicians. The authors also proposed the incorporation of periodic emergency exercises in dental settings, along with continuing education courses, to help dental surgeon manage ME.

A national study ${ }^{4}$ of 498 professionals found that Brazilian dental surgeon are not fully prepared to manage ME, as only $41 \%$ of dental surgeon thought they could diagnose the cause of $\mathrm{ME}$, and most felt unable to treat situations of anaphylaxis, myocardial infarction or cardiac arrest, or dealing with cardiopulmonary resuscitation procedures and intravenous injection. Another important finding of the study is that the most common justifications for lack of knowledge and skills were lack of training and updating during and after the undergraduate course.

Despite geographical differences and variability in dental curricula around the world, studies show that students and practitioners have expressed their intention to improve their specific set of ME management skills ${ }^{5,34}$. We believe that undergraduate dentistry courses should be reviewed to make it mandatory to include ME in their curricula, and that this agenda should be raised by the Brazilian Association of Dental Education (ABENO). Likewise, upon graduation, all trained professionals, regardless of whether they are specialists, should be encouraged to take regular CFO-regulated theoretical and practical courses in the field, and more severely in the future become mandatory for record keeping from the board.

A limitation of this study is the impossibility of identifying institutions that offer subject-oriented extracurricular projects related to the subject. Another limitation is to have evaluated and included only disciplinary 'by name', but that the content could be approached in a theoretical or theoretical-practical way within another discipline, such as physiology, pharmacology and surgery, which can generate a possible analysis bias. However, it was not the objective at this time and due to the difficulty of accessing all menus for this type of evaluation. One suggestion is that future studies conduct an assessment based on semi-structured questionnaires sent to course coordinators to obtain additional information related to the prepa- 
ration of dental schools to respond to medical emergencies. The HEl exclusion criteria adopted in this study culminated in an inclusion rate of $81.8 \%$ of institutions in southeastern Brazil. Therefore, the results discussed here reflect the reality of most HEls in this region, but they should not be generalized as the real situation of teaching ME.

The evaluation of higher education curricula and discussions that lead to curricular changes are essential to achieve excellence in teaching ${ }^{35-38}$. It is important that the curricula of undergraduate courses in Dentistry are reviewed to make it mandatory to include this discipline, in order to improve knowledge and practice in $\mathrm{ME}$, providing the skills that will allow a well trained professional to attend the needs of the patients. This need should be discussed by the ABENO and by the CFO, in order to formulate a consensus document that guides the $\mathrm{HEl}$ in future curricular reformulations, such as fundamental program content, minimum workload, offer period, nature of the discipline and methodologies of teaching ideas.

In conclusion, this study observed the current panorama of the supply of the discipline of medical emergencies in dentistry courses, and observed that dental schools in southeastern Brazil, both public and private, are outdated in the curriculum, since most HEls do not offer the discipline (81.25\%). In addition to the low supply of the discipline, in most institutions the discipline is only theoretical. It is also noteworthy that, within the theoretical modality, more than a quarter of the HEls offer the discipline in the distance learning modality, which can raise questions about the quality of practical teaching. As a positive point, it was observed that when offered the nature of the discipline is predominantly mandatory.

\section{REFERENCES}

1. Haas DA. Management of medical emergencies in the dental office: conditions in each country, the extent of treatment by the dentist. Anesth Prog. 2006; 53(1):20-4. doi: 10.2344/0003-3006(2006)53[20:MOMEIT]2.0.CO;2.

2. de Bedout T, Kramer K, Blanchard S, Hamada Y, Eckert GJ, Maupome G, et al. Assessing the medical emergency preparedness of dental faculty, residents, and practicing periodontists: an exploratory study. J Dent Educ. 2018 May; 82(5):492-500. doi: 10.21815/JDE.018.058.

3. Vaughan M, Park A, Sholapurkar A, Esterman A. Medical emergencies in dental practice management requirements and international practitioner proficiency. A scoping review. Aust Dent J 2018 Dec;63(4):455-66. doi: 10.1111/adj.12649.

4. Arsati F, Montalli VA, Flório FM, Ramacciato JC, da Cunha FL, Cecanho R, et al. Brazilian dentists' attitudes about medical emergencies during dental treatment. J Dent Educ. 2010 Jun;74(6):661-6.

5. Stafuzza TC, Carrara CF, Oliveira FV, Santos CF, Oliveira TM. Evaluation of the dentists' knowledge on medical urgency and emergency. Braz Oral Res. 2014;28:S1806-83242014000100240. doi: 10.1590/10.1590/1807-3107bor-2014.vol28.0029

6. Fiuza MK, Balsan ST, Pretto JLB, Cenci RA; de Conto F. [Assessment of prevalence and knowledge level of dental surgeons regarding medical emergencies]. RFO UPF. 2013 Sep/Dec;18(3):295-301. Portuguese. 
7. Santos JC, Rumel D. [Medical emergency in dental practice: occurrence, equipments and drugs, professional expertise and training of the clinicians]. Cienc Saude Colet. 2006;11(1):183-90. Portuguese. doi: 10.1590/S1413-81232006000100027.

8. Smereka J, Aluchna M, Aluchna A, Szarpak Ł. Preparedness and attitudes towards medical emergencies in the dental office among Polish dentists. Int Dent J. 2019 Aug;69(4):321-8. doi: $10.1111 /$ idj. 12473 .

9. Azad A, Talattof Z, Deilami Z, Zahed M, Karimi A. Knowledge and attitude of general dentists regarding common emergencies in dental offices: A cross-sectional study in Shiraz, Iran. Indian J Dent Res. 2018 Sep-Oct;29(5):551-5. doi: 10.4103/ijdr.IJDR_587_16.

10. Čuković-Bagić I, Hrvatin S, Jeličić J, Negovetić Vranić D, Kujundžić Tiljak M, Pezo H, et al. General dentists' awareness of how to cope with medical emergencies in paediatric dental patients. Int Dent J. 2017 Aug;67(4):238-43. doi: 10.1111/idj.12286.

11. Khami MR, Yazdani R, Afzalimoghaddam M, Razeghi S, Moscowchi A. Medical emergency management among Iranian dentists. J Contemp Dent Pract. 2014 Nov;15(6):693-8. doi: 10.5005/jp-journals-10024-1601.

12. Adewole RA, Sote EO, Oke DA, Agbelusi AG. An assessment of the competence and experience of dentists with the management of medical emergencies in a Nigerian teaching hospital. Nig Q J Hosp Med. 2009 Sep-Dec;19(4):190-4.

13. Marks LA, Van Parys $C$, Coppens $M$, Herregods L. Awareness of dental practitioners to cope with a medical emergency: a survey in Belgium. Int Dent J. 2013 Dec;63(6):312-6 doi: 10.1111/idj.12046.

14. Gupta T, Aradhya MR, Nagaraj A. Preparedness for management of medical emergencies among dentists in Udupi and Mangalore, India. J Contemp Dent Pract. 2008 Jul 1;9(5):92-9.

15. Marti K, Sandhu G, Aljadeff L, Greene R, Lesch AB, Le JM, et al. Simulation-Based Medical Emergencies Education for Dental Students: A Three-Year Evaluation. J Dent Educ. 2019 Aug;83(8):973-80. doi: 10.21815/JDE.019.084.

16. Roy E, Quinsat VE, Bazin O, Lesclous P, Lejus-Bourdeau C. High-fidelity simulation in training dental students for medical life-threatening emergency. Eur J Dent Educ. 2018 May;22(2):e261-8. doi: 10.1111/eje.12284.

17. Sopka S, Biermann H, Druener S, Skorning M, Knops A, Fitzner C, et al. Practical skills training influences knowledge and attitude of dental students towards emergency medical care. Eur J Dent Educ. 2012 Aug;16(3):179-86. doi: 10.1111/j.1600-0579.2012.00740.x.

18. Balmer MC. A dental undergraduate course for the management of medical emergencies in dental practice. Eur J Dent Educ. 2008 Nov;12(4):239-46. doi: 10.1111/j.1600-0579. 2008.00525.x.

19. Newby JP, Keast J, Adam WR. Simulation of medical emergencies in dental practice: development and evaluation of an undergraduate training programme. Aust Dent J. 2010 Dec;55(4):399- 404. doi: 10.1111/j.1834-7819.2010.01260.x.

20. Tanzawa T, Futaki K, Kurabayashi H, Got K, Yoshihama Y, Hasegawa T, et al. Medical emergency education using a robot patient in a dental setting. Eur J Dent Educ. 2013 Feb;17(1):e114-9. doi: 10.1111/j.1600-0579.2012.00770.x.

21. Fast $T$, Graham W. Curricular guidelines for management of medical emergency in dental education. J Dent Ed 1981;45(6):379-81. doi: 10.1002/j.0022-0337.1981.45.6.tb01476.x.

22. Federal Council of Dentistry of Brazil. [Resolution CFO-63 of 2005 April 8. Art. 171. Consolidation of Norms for Procedures in Dentistry Councils]. Brasília: Federal Council of Dentistry; 2005. [cited 2019 Dec 17]. 86p. Available from: http://transparencia.cfo.org.br/wp-content/uploads/2018/03/ consolidacao.pdf. Portuguese.

23. Carvalho RM, Costa LR, Marcelo VC. Brazilian dental students' perceptions about medical emergencies: a qualitative exploratory study. J Dent Educ. 2008 Nov;72(11):1343-9. 
24. Ministry of Education of Brazil. [E-MEC Register of Higher Education Institutions and Courses]. Brasília: Ministry of Education; 2019. [cited 2019 Mar 8]. Available from: http://emec.mec.gov.br. Portuguese.

25. Ministry of Education of Brazil. [Normative Ordinance No. 21, of 2017 December 21]. Brasília: Union Official Diary; 2017 [cited 2019 Mar 8]. Available from: https://www.in.gov.br/materia/-/asset_ publisher/Kujrw0TZC2Mb/content/id/1284644/do1-2017-12-22-portaria-n-21-de-21-de-dezembro -de-2017-1284640-1284640. Portuguese.

26. Bell G, James H, Kreczak H, Greenwood M. Final-year dental students' opinions of their training in medical emergency management. Prim Dent J. 2014 Feb;3(1):46-51. doi: 10.1308/205016814812135797.

27. Ministry of Education of Brazil. National Education Council. Higher Education Chamber. [National Curricular Guidelines for the Undergraduate Dentistry Course]. Brasília: Union Official Diary; 2018. [cited 2019 Dec 17]. 19p. Available from: http://portal.mec.gov.br/docman/abril-2019-pdf/111231pces803-18/file. Portuguese.

28. Presidency of the Republic of Brazil. [Law No. 5,081, of 1966 August 24. Regulates the Practice of Dentistry]. Brasília: Union Official Diary; 1966. [cited 2019 Dec 17]. Available from: http://www.planalto.gov.br/ccivil_03/leis/L5081.htm. Portuguese.

29. Presidency of the Republic of Brazil. [Law no 9.394, of 1996 December 20. Establishes the guidelines and bases of national education]. Brasília: Union Official Diary; 1996. [cited 2019 Dec 17]. Available from: http://www.planalto.gov.br/ccivil_03/leis/19394.htm. Portuguese.

30. Malamed SF. [Medical emergencies in the dental office]. $7^{\text {th }}$ ed. Rio de Janeiro: GEN Guanabara Koogan; 2016. Portuguese.

31. Lawson L. Medical emergency preparedness in dental practice. RDH. 2017;37(6):47-59.

32. Vaughan M, Mahoney G, Sholapurkar A, Ray RA. Patients' views on dentists' ability to manage medical crises - results of focus group research. Aust Dent J. 2019 Dec;64(4):338-45. doi: 10.1111/adj.12717.

33. Le TT, Scheller EL, Pinsky HM, Stefanac SJ, Taichman RS. Ability of dental students to deliver oxygen in a medical emergency. J Dent Educ. 2009 Apr;73(4):499-508.

34. Campos ACM, Assis NMSP, Leite ICG, Silva BN, Carvalho MF. [Knowledge level of basic life support among dentistry students]. HU Rev. 2019;45(2):170-6. Portuguese. doi: 10.34019/1982-8047.2019.v45.26684.

35. Faria LV, Oliveira GA, Grázzia MEP, Medeiros YL, Lopes DF, Leite ICG. [The teaching of implant dentistry in Brazilian dentistry graduations: a cross-sectional study]. REAS. 2020 Mar;12(4):e2672. Portuguese. doi: 10.25248/reas.e2672.2020.

36. Medeiros YL, Lopes DF, Faria LV, Soares MRPS, Silvério CCP. Brazilian Sign Language teaching in dentistry undergraduate courses at Southeastern Brazil: a cross-sectional study. Rev ABENO. 2020; 20(1):113-20. doi: 10.30979/rev.abeno.v20i1.933.

37. Medeiros YL, Faria LV, Lopes DF, Oliveira IS, Fabri GMC. [Insertion of Hospital Dentistry in the curricular grade of the southeast brazilian Dentistry courses]. Rev. Fac. Odontol. Porto Alegre. 2020; 61(1):87-93. Portuguese. doi: 10.22456/2177-0018.101594.

38. Faria LV, Medeiros YL, Lopes DF, Durso BD. [TMD and orofacial pain: curricular perspectives of dental schools in Southeast Brazil]. HU Rev. 2020;46:1-7. Portuguese. doi: 10.34019/1982-8047.2020.v46.30348. 